Крайнова Тетяна Іванівна

Громадська організація «Міждисциплінарний інститут розвитку»

\title{
АКТУАЛЬНІ ПИТАННЯ СПІВПРАЦІ СОЦАЛЬНОГО ЕКСПЕРТНО-КООРДИНАЦІЙНОГО КОМІТЕТУ І ЕКСПЕРТНО-КООРДИНАЦЙНИХ ГРУП \\ ЗАГАЛЬНООСВІТНИХ ЗАКЛАДІВ У НАПРЯМІ РОЗВИТКУ РОЗШИРЕНОГО ІНКЛЮЗИВНОГО ПРОСТОРУ
}

У статті висвітлюеться актуальність створення сочіальної експертно-координаційної групи фахівців інклюзивного напряму. Також відзначаються особливості ї̈ роботи $і$ напрямки співпраці $з$ експертно-координаційними групами загальноосвітніх навчальних закладів.

Ключові слова: інклюзивний розвиток, суспільство, сочіальна експертно-координаційна група, співпраця, цілісний інклюзивний простір.

Проблема, ïï зв'язок із важливими науковими чи практичними завданнями. Інтеграція України до країн $\epsilon C$ активує соціальні зміни, які відбуваються у прискореному темпі і часто за відсутності попереднього практичного досвіду. Головна задача суспільства в таких екстремальних умовах - це пошук найбільш ефективних форм і методів втілення інновацій, формування нового практичного досвіду i нової ідентичності, які б в той же час забезпечували збереження психічного і фізичного здоров'я громадян.

Однією 3 інтеграційних тенденцій європейського напрямку $є$ інклюзивний розвиток суспільства, який розпочався в Україні 3 інклюзивної освіти і поширився на даний час на інші напрями соціального життя, створюючи розширений інклюзивний простір [1]. Ці процеси охоплюють дітей з особливими потребами, їх батьків, дітей типового рівня розвитку та їх сім’і, педагогів, психологів, медиків, архітекторів, які планують доступність простору, дорослих людей 3 особливими потребами. На інклюзивну тенденцію відгукуються книжкові видавництва, театри, бібліотеки, спортивні та інші організації. Високий рівень інноваційного навантаження на суспільство, який складається при цьому, потребує створення не тільки інклюзивно-ресурсних центрів, орієнтованих на освітні цілі [2], а й єдиної інстанції в соціальному секторі, яка б взяла на себе відповідальність за системне вивчення, планування, наукову розробку 
та реалізацію інклюзивного розвитку широкого соціального середовища. Таким чином, набуває актуальності питання створення соціально спрямованого інклюзивного ресурсного центру та формування на його базі компетентного в інклюзивних питаннях об'єднання фахівців. Цим об'єднанням може стати міждисциплінарна експертно-координаційна група (комітет), орієнтована на активну співпрацю 3 експертно-координаційними групами загальноосвітніх закладів та з інклюзивно-освітніми ресурсними центрами.

Аналіз публікацій (виділення невирішених проблем). При вивченні літературних джерел з'ясовано, що питання розвитку інклюзивних тенденцій в соціальному секторі i співпраця інших організацій з інклюзивними загальноосвітніми навчальними закладами в науковій літературі висвітлені недостатньо. На необхідність такої співпраці вказують А. Колупаєва, О. Таранченко, І. Білозерська, але головною сполучною ланкою між школою та соціальним середовищем, з їх погляду, є батьки дітей. В літературі все частіше висловлюється думка, що сучасні школи значною мірою втратили зв'язок із суспільством. На дану проблему вказує Елкінз (Elkins). На потребу в покращенні зв'язків між школою і громадою звертається увага i в навчально-методичному посібнику «Індекс інклюзії: загальноосвітній заклад» [3, с. 172]. В ньому вказується близько п'ятдесяти рекомендованих організацій, які можуть давати додаткові інклюзивні ресурси, але без об’єднуючої організації співробітництво 3 ними теж буде ускладнено. Таким чином, аналіз літературних джерел свідчить про те, що інклюзивна робота в соціальному секторі та співпраця інклюзивно спрямованих соціальних організацій 3 інклюзивними освітніми навчальними закладами системно не вивчалась.

Ціль статті - висвітлити актуальність створення соціальної експертно-координаційної групи фахівців (комітету), позначити іiі особливості, намітити перші практичні кроки у співпраці з експертнокоординаційними групами загальноосвітніх закладів.

Виклад основного матеріалу, обгрунтування результатів дослідження. В основі створення соціальної експертнокоординаційної групи фахівців полягає міждисциплінарний підхід до інклюзивного розвитку громади. Ця група складається з компетентних в інклюзивних питаннях спеціалістів: представників департаментів місцевої влади, представників громадських організацій, соціологів, психологів, педагогів, представників медичного сектору, ювенальної поліції, архітекторів та інших представників, включених в процес інклюзивного розвитку розширеного інклюзивного простору. Велике значення має активна діяльність в групі батьків дітей 3 особливими потребами та дітей типового рівня розвитку. 


\section{Збірник наукових статей}

Діяльність соціальної експертно-координаційної групи спрямована на вивчення, планування, наукову розробку та реалізацію інклюзивного розвитку широкого соціального середовища, координацію співпраці, як у межах соціального сектору, так i 3 експертно-координаційними групами загальноосвітніх навчальних закладів.

Між соціальною експертно-координаційною групою i експертно-координаційними групами загальноосвітніх закладів $\epsilon$ загальні позиції, а також суттєві відмінності. Як і у випадку роботи експертно-координаційних груп у загальноосвітніх навчальних закладах, соціальна експертно-координаційна група має своєю першочерговою метою запровадження єдиного інклюзивного підходу, але цей підхід стосується розвитку позашкільного соціального простору. Виходячи 3 цього, головним об'єктом первинного дослідження соціальної експертно-координаційної групи $\epsilon$ не навчальний процес, а позашкільна діяльність дітей у розширеному інклюзивному середовищі. До такої діяльності відноситься: природжена вільна дитяча гра, інші ऑiі види та форми, вільне спілкування, діяльність, спрямована на придбання практичного життєвого досвіду, розвиток в гуртках за інтересами, спортивний розвиток, активний відпочинок та інше. Подальше визначення пріоритетів інклюзивного розвитку соціального розширеного простору, усунення бар'єрів на його шляху, складання скоординованої єдиної програми і плану її реалізації, моніторинг успішності заходів пов'язані саме з цими видами дитячої діяльності.

Друга особливість соціальної експертно-координаційної групи полягає у новаторському характері iii роботи, який обумовлено відсутністю теоретичних та практичних матеріалів, спрямованих на планування дій зі створення та розвитку широкого соціального простору інклюзивного характеру. Частково ці матеріали можуть бути взяті з літератури, спрямованої на розвиток інклюзивної освіти. Так, «Індекс інклюзії: розвиток навчання та участі в життєдіяльності шкіл» $[3$, с. 75-159] пропонує три напрями інклюзивного розвитку у загальноосвітньому навчальному закладі, 3 яких перші два можуть бути адаптовані зусиллями соціальної експертно-координаційної групи. Це такі напрями, як «А: Створення інклюзивної культури», який включає в себе розбудову спільноти і формування інклюзивних цінностей, і «Б: Розроблення інклюзивної політики», який створює «простір для всіх» та підтримує різноманітність. Що стосується напряму «В: Розвиток інклюзивної практики», то він потребує зміни 3 «організації навчання» на організацію інклюзивної дитячої гри, вільного спілкування, придбання інклюзивно спрямованого життєвого 
Психолого-педагогічні проблеми становлення сучасного фахівця Випуск 2018 досвіду та інші активності, які складають розширений інклюзивний позашкільний простір дітей.

Також одним 3 головних напрямків наукової діяльності експертно-координаційної соціальної групи $\epsilon$ пошук заходів підвищення мотивації дітей типового рівня розвитку у спілкуванні 3 дітьми 3 особливими потребами в умовах вільного вибору, які відрізняються від шкільних, де дитина типового рівня не має можливості вільно залишити інклюзивний простір. Таким чином, діяльність соціальної експертно-координаційної групи має новаторський i науково-дослідницький характер та спрямована на пошук і наукову розробку найбільш ефективних способів розвитку розширеного інклюзивного простору за межами загальноосвітніх навчальних закладів.

Ще однією особливістю соціальної експертно-координаційної групи та іiі відмінність від експертно-координаційної групи загальноосвітнього закладу $є$ склад більш широкого професійного діапазону. Поєднання у своїй роботі тих фахівців, які не мали до цього досвіду співпраці, потребує додаткової уваги і наукового дослідження. 3 одного боку, такий міждисциплінарний альянс дає змогу шляхом «злиття професійних горизонтів» розширити i поглибити знання i досвід стосовно інклюзивних процесів, 3 другого, може стати платформою для активації соціальних стереотипів, непорозуміння, відчуженості, або навпаки, розмивання професійних меж. Запобіганням цих негативних процесів повинні стати систематичні тренінги, відкриті дискусії, міжнародні конференції за участю більш досвідчених у питанні формування розширеного соціального простору фахівців.

Не зважаючи на те, що між роботою соціальних експертнокоординаційних груп i експертно-координаційніх груп загальноосвітніх закладів є суттєві відмінності, в цілому їх робота спрямована на єдину ціль - формування цілісного інклюзивного світогляду у дітей і батьків, у педагогічного і міждисциплінарного колективу та на розвиток безперервного інклюзивного простору.

Співпраця між цими інклюзивно орієнтованими об'єднаннями полягає у наступних заходах:

1. Ознайомлення $з$ планами розвитку інклюзивного середовища у загальноосвітньому і розширеному соціальному просторі.

2. Пошук взаємодоповнюючих спільних дій у напрямі формування безперервного інклюзивного простору.

3. Створення скоординованої програми розвитку безперервного інклюзивного простору і плану їі реалізації.

4. Аналіз ефективності спільних заходів розвитку безперервного інклюзивного простору. 


\section{Збірник наукових статей}

5. Пошук подальших спільних дій у напрямі формування розширеного інклюзивного простору. напрямі.

6. Міждисциплінарні наукові дослідження у інклюзивному

7. Підведення підсумків спільної скоординованої роботи соціального експертно-координаційного комітету i експертнокоординаційних груп загальноосвітніх закладів на міждисциплінарних засіданнях, науково-практичних форумах, конференціях, конгресах.

Перші кроки 3 формування соціальної експертнокоординаційної групи i організації співпраці 3 інклюзивними загальноосвітніми навчальними закладами почато у соціальному центрі «Сім'я» міста Харкова.

Висновки, перспективи. Створення соціальної експертнокоординаційної групи фахівців (комітету), її співпраця з експертнокоординаційними групами загальноосвітніх закладів, 3 інклюзивноосвітніми ресурсними центрами дадуть змогу змінити фрагментарний характер інклюзивного розвитку українського суспільства на цілісний взаємодоповнюючий процес. Це сприятиме успішному формуванню єдиного інклюзивного простору і інклюзивному світогляду громадян нашої країни, дасть змогу уникнути багатьох травмопотенційних ситуацій і позитивно впливатиме на їх здоров'я.

Подальшого вивчення потребують питання поглибленої співпраці соціальної експертно-координаційної групи (комітету) і експертно-координаційних груп загальноосвітніх закладів.

\section{Література}

1. Крайнова Т. І. Від інклюзивної освіти - до інклюзивної громади: актуальні питання міждисциплінарного розвитку розширеного інклюзивного простору / Т. І. Крайнова // Актуальні питання освіти і науки: зб. наук. ст., матеріали V міжнар. наук.-практ. конф., 10-11 листоп. 2017 р. - Х. ХОГОКЗ, 2017. - С. 340-346.

2. Про затвердження Положення про інклюзивно-ресурсний центр. Постанова Кабінету Міністрів України від 12 липня 2017 р. № 545, Київ [Електронний ресурс]. - Режим доступу : http://zakon2.rada.gov.ua/laws/show/545-2017.

3. Індекс інклюзії: розвиток навчання та участі в життедіяльності шкіл: посібник / Тоні Бут [пер. 3 англ.] - К. : ТОВ Видавничий дім «Плеяди», 2015. - 190 с.

4. Колупаєва А. А. Професійне співробітництво в інклюзивному навчальному закладі: навч. метод. посіб. / А. А. Колупаєва, Е. А. Данілавічюте, С. В. Литовченко. - К. : Видавнича група «А.С.К.», 2012. - 192 c. 
Психолого-педагогічні проблеми становлення сучасного фахівця Випуск 2018

5. Колупаєва А. Інклюзивна освіта як модель соціального устрою / А. Колупаєва // Особлива дитина: навчання і виховання. 2014. - № 2. - С. 7-18.

6. Основи інклюзивної освіти : навч.-метод. посіб / За заг. ред. Колупаєвої А. А. - К. : «А.С.К.», 2012. - 308 с.

Татьяна Крайнова. Актуальные вопросы сотрудничества социального экспертно-координационного комитета и общеобразовательных экспертно-координационных групा в направлении развития расширенного инклюзивного пространства.

В статье освещчается актуальность создания соцчиальной экспертнокоординационной группь специалистов инклюзивного направления. Также отмечаются особенности её работь и направления сотрудничества с експертно-координационными группами общеобразовательных учебных заведений.

Ключевые слова: инклюзивное развитие, общество, социальная экспертно-координационная группа, сотрудничество, целостное инклюзивное пространство.

Tatyana Krainova. The topical issues of cooperation of the social expert-coordinating committee and general educational expertcoordinating groups in the direction of development an expanded inclusive space.

The urgency of creating the social expert-coordinating group of specialists of an inclusive direction is covered in this article. Also features of its work and the implementation of cooperation with expert-coordination groups are noted in the article.

Keywords: inclusive development, society, social expert-coordinating group, cooperation, holistic inclusive space.

Стаття надійшла до редакційної колегії 08.05.2018

Прийнято до друку 09.05.2018

Інформація про автора:

Крайнова Тетяна Іванівна - Голова Правління, громадська організація «Міждисциплінарний інститут розвитку». 